2005

\title{
The Jurisprudence of Justice Esther Tomljanovich: Balancing the Scales of Justice
}

Ann L. Iijima

Follow this and additional works at: http://open.mitchellhamline.edu/wmlr Part of the Judges Commons, and the Jurisprudence Commons

\section{Recommended Citation}

Iijima, Ann L. (2005) "The Jurisprudence of Justice Esther Tomljanovich: Balancing the Scales of Justice," William Mitchell Law Review: Vol. 32: Iss. 1, Article 6.

Available at: http://open.mitchellhamline.edu/wmlr/vol32/iss1/6

This Article is brought to you for free and open access by the Law Reviews and Journals at Mitchell Hamline Open Access. It has been accepted for inclusion in William Mitchell Law Review by an authorized administrator of Mitchell Hamline Open Access. For more information, please contact sean.felhofer@mitchellhamline.edu.

(C) Mitchell Hamline School of Law

\section{$\mathrm{MH}$}

MITCHELL | HAMUINE OPEN ACCESS selod of the

mitchellhamline.edu 


\title{
THE JURISPRUDENCE OF JUSTICE ESTHER TOMLJANOVICH: BALANCING THE SCALES OF JUSTICE
}

\author{
Ann L. Iijima ${ }^{\dagger}$

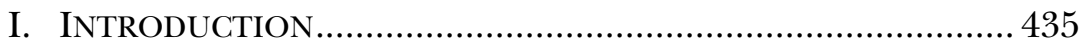

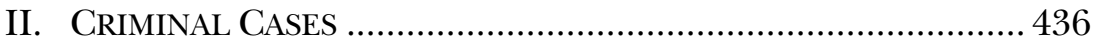

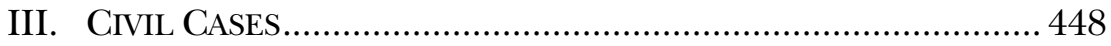

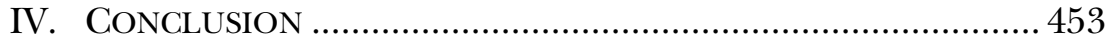

Judging is an exercise of personal and institutional character. It is a delicate mixture of logic tempered by wisdom, reflection, imagination, and as much detachment as a trained mind can achieve .... [J] udging requires a tense engagement between the competing arguments in a case-an honest statement of the most powerful theories underlying each side's view. The Court's role as interpreter of our most basic law demands no less. ${ }^{1}$

\section{INTRODUCTION}

It is easy to become disheartened and cynical about the judiciary when reading Lazarus's description of the inner workings of the Court in Closed Chambers: The Rise, Fall, and Future of the Modern Supreme Court. Unlike his vision of what he thinks the United States Supreme Court should be, Professor Edward Lazarus describes the actual Court as a flawed, dysfunctional body, where the Justices decide the most controversial (and arguably most

$\dagger \quad$ Ann L. Iijima is a Professor of Law at William Mitchell College of Law. She thanks Malinda Schmiechen for her research assistance and insights. This article has been adapted from MINN. STATE LAW LIBRARY, The Judicial Career of Esther M. Tomljanovich, in 14 Minn. Justices SERIEs (Barbara Golden \& Anna M. Cherry eds.) (forthcoming Sept. 2005) with the permission of the Minnesota State Law Library.

1. Edward Lazarus, Closed Chambers: The Rise, Fall, and Future of the Modern Supreme Court 286 (Penguin Books 1999) (1998). 
important) issues based on their personal predilections, and where the rule of law is determined by a mere majority vote. Lazarus observes that "[d] eep cynics in legal academia make fun of the idea that there is more to lawmaking and judging than the exercise of power."

After reading the opinions of Justice Esther Tomljanovich, even legal cynics may regain their faith in the judicial process and their belief that our courts, both state and federal, can aspire to Lazarus's alternative vision.

A number of themes appear on a recurring basis in Justice Tomljanovich's opinions: an effort to balance the interests of society in both individual freedom and public order; a preference for deciding cases on narrow, clearly defined bases rather than announcing broad constitutional principles; a belief in the separation of powers; the protection of privacy rights, particularly those involving the sanctity of the home; a reluctance to engage in results-oriented decision-making, preferring instead to promote and trust in a well-functioning legal system; and the use of logic and common sense.

These themes may reflect an unusual breadth and depth of experience. Her small-town upbringing in northern Minnesota may have grounded her in the everyday lives and needs of working people. Her struggles as a woman working her way through maledominated professions may have reinforced an inherent inclination to take a relatively temperate approach to legal issues. Her experiences with the legislature as the Revisor of Statutes and as a trial and appellate judge may have increased her understanding of both the roles and the limits of those institutions.

\section{CRIMINAL CASES}

Justice Tomljanovich's opinions in criminal cases are illustrative, particularly in her dissenting opinions, where she was empowered to voice her thoughts free of majority-garnering compromise.

One such dissenting opinion involved the infamous defendant, Dennis Darol Linehan, who committed numerous rapes and sexual assaults—kidnapping and killing one of his victims. ${ }^{3}$ After serving

2. Id.

3. In re Linehan, 557 N.W.2d 171 (Minn. 1996). 
his sentence, Linehan was committed indefinitely to state treatment facilities under the Sexually Dangerous Persons (SDP) Act, a civil commitment statute. ${ }^{4}$

It was clear in which direction the arrow of political expediency pointed. In a special legislative session just before the statewide primary elections, the Minnesota House and Senate both passed the SDP Act by unanimous votes. ${ }^{5}$ The district court, the Minnesota Court of Appeals, and the Minnesota Supreme Court all upheld the constitutionality of the SDP Act. ${ }^{6}$

Justice Tomljanovich dissented, chiding the majority for "shirk[ing] its duty to uphold appellant's right to substantive due process ...." She quoted from Justice Kennedy's concurring opinion in Texas $v$. Johnson, the flag-burning case:

"The case before us illustrates better than most that the judicial power is often difficult in its exercise .... The hard fact is that sometimes we must make decisions we do not like. We make them because they are right, right in the sense that the law and the Constitution, as we see them, compel the result."

By affirming the trial court's civil commitment of Dennis Darol Linehan ... , this court today chooses to make the easy decision. Not because it is right, not because it is compelled by the constitutions of either the United States or Minnesota, but because it is convenient .... And what is the basis upon which the majority reaches this conclusion? It is the fear of Dennis Darol

4. Id. at 174-76 (Minn. 1996), vacated sub nom. Linehan v. Minnesota, 522 U.S. 1011 (1997), remanded to 594 N.W.2d 867 (Minn. 1999) (on remand for consideration in light of Kansas v. Hendricks, 521 U.S. 346 (1997)). On remand, the Minnesota Supreme Court again held that the SDP Act did not violate substantive due process. In re Linehan, 594 N.W.2d 867, 878 (Minn. 1999). Three Justices disagreed, not including Justice Tomljanovich, who had retired the previous year. See id. at 878-85 (Page, J., dissenting); id. at 885-87 (Lancaster, J., concurring and dissenting in part, joined by Anderson, J.).

5. In re Linehan, 557 N.W.2d at 198 (Tomljanovich, J., dissenting).

6. Id. at 174-75 (majority opinion).

7. Id. at 192 (Tomljanovich, J., dissenting). Justice Page joined Justice Tomljanovich's dissenting opinion and also wrote his own dissent. Id. at 206. He noted that the sentence Linehan received was not sufficiently severe and that, although the constitution would have allowed a sentence of life in prison without the possibility of release, it did not allow preventive detention. Id. at 200 (Page, J., dissenting).

8. Id. at 191 (Tomljanovich, J., dissenting) (quoting Texas v. Johnson, 491 U.S. 397, 420-21 (1989) (Kennedy, J., concurring)). 
Linehan and what he might do upon his release. ${ }^{9}$

She concluded that "the Due Process Clause of the Constitution prohibits us as a society from locking up persons simply because we fear them . . . even if the future bad acts are almost certain to occur." $" 10$

In State v. Paul, ${ }^{11}$ Justice Tomljanovich's reading of the Constitution again required her to take an unpopular position. In Paul, the majority held that a police "officer in hot pursuit of a person suspected of . . . driving under the influence of alcohol may make a warrantless entry into the suspect's home." ${ }^{2}$ In her dissenting opinion, Justice Tomljanovich acknowledged the important interests of the state in protecting public safety. "I believe, as do the majority of thinking people, that drunk driving is a very serious offense. I agree that drunk drivers should be removed from the public highways because their actions are intolerable." ${ }^{13}$ She reasoned, however, that Paul's privacy interests outweighed the interests of the State. "If there is any place in the world we should feel secure and have an expectation of privacy, it is in our own homes. Today, the majority has made us less secure in those homes without enhancing public safety." expand the previously recognized exceptions to the warrant requirement.

9. Id. at 191-92 (Tomljanovich, J., dissenting).

10. Id. at 195 .

11. 548 N.W.2d 260 (Minn. 1996).

12. Id. at 267 .

13. Id. at 268 .

14. Id.

15. Another example of this reluctance is seen in Justice Tomljanovich's majority opinion in State v. Varnado, 582 N.W.2d 886 (Minn. 1998). In Varnado, she refused to extend any of the "well-established exceptions to the Fourth Amendment's search warrant requirement" to allow police to search a person suspected of a minor traffic violation before placing the person in the back of the squad car. Id. at 887 .

Under the state's proposed rule . . . no articulable suspicion would be necessary for a frisk. Any stop for a minor traffic violation when the driver does not have a driver's license . . . would ultimately provide sufficient cause for a frisk because an officer would merely have to request that a stopped person wait in the squad car during the license check. Such a procedure would essentially eliminate any Fourth Amendment protection against unreasonable searches in traffic stops.

Nonetheless, we agree that officer safety is a paramount interest and that when an officer has a valid reasonable basis for placing a lawfully stopped citizen in a squad car, a frisk will often be appropriate without additional individual articulable suspicion. 
[E]ven with hot pursuit and exigent circumstances a warrantless entry into a home for a misdemeanor offense is unreasonable .... Our laws have provided for limited entry under warrant, consent, emergency or exigent circumstances when a felony is involved. We should not stretch that limitation to break the promise of the constitutional rights of our citizens to be secure in their homes. $^{16}$

Justice Tomljanovich's dissent also raised the separation of powers issue. It emphasized that our system of justice requires both the executive and judicial departments to fulfill their roles.

The framers of the Fourth Amendment incorporated the warrant requirement into it, "reflecting their conviction that the decision to enter a dwelling should not rest with the officer in the field, but rather with a detached, and disinterested Magistrate." What the majority does today is allow an officer in the field to make the determination for warrantless entry into a private dwelling. It is here that I disagree. The majority would impugn the intelligence of our police officers by telling us that the officers cannot know whether an offense is a felony or misdemeanor before entering a home. Police officers know the law; they know whether they have a felony or misdemeanor on their hands. ${ }^{17}$

Justice Tomljanovich seemed particularly protective of the rights of criminal defendants where, as in Paul, the government's actions implicated privacy rights as well as Fourth Amendment rights.

"The poorest man may in his cottage bid defiance to all the forces of the Crown. It may be frail; its roof may shake; the wind may blow through it; the storm may enter; the rain may enter; but the King of England cannot enter-all his forces dares not cross the threshold of the ruined tenement!" Our forefathers believed as passionately in the sanctity of the home as do I. They drafted the Fourth Amendment to deny federal law enforcement such intrusive entry and the Fourteenth Amendment extended that restriction to state law enforcement personnel as well. Our own Minnesota

Id. at 891 .

16. 548 N.W.2d at 268-69 (Tomljanovich, J., dissenting).

17. Id. at 269 (quoting Payton v. New York, 445 U.S. 573, 582 n.17 (1980)). 
Constitution echoes those same tenets and we should not now decide that the Crown may enter with the storm! ${ }^{18}$

State v. Wynne $e^{19}$ also implicated both Fourth Amendment and privacy issues. In Wynne, the police executed a warrant to search Joy Pamela Wynne's residence, her person, and any other person

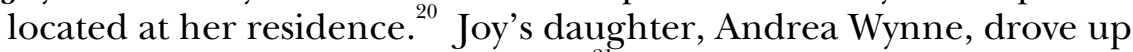
while the search was in progress. ${ }^{21}$ Police officers took Andrea Wynne's purse from her and escorted her into the house. ${ }^{22}$ They found controlled substances in her purse and charged her with felony possession. ${ }^{23}$

Justice Tomljanovich's majority opinion held that the search was unconstitutional. ${ }^{24}$ The opinion carefully parsed through a number of exceptions to the warrant requirement, finding that none justified the search of the defendant's purse. ${ }^{25}$ It leavened a thorough examination of precedent with a liberal dose of logic and common sense. Discussing whether the search fell within the Terry ${ }^{26}$ doctrine, it stated:

When Andrea Wynne arrived at her home, officers met her at the car in which she arrived, determined that she was an occupant of the premises being searched, took her purse and walked her and separately her purse, into the house. First, we fail to understand how the purse remained a threat to officers when it had been taken away from its owner. Second, even if we accepted that the purse did remain a threat because Andrea Wynne could somehow have retrieved it from officers inside the house, it was a threat that the officers themselves created by bringing the purse inside the house. The officers then went about remedying the self-generated dangerous

18. Paul, 548 N.W.2d at 269-70 (Tomljanovich, J., dissenting) (quoting Miller v. United States, 357 U.S. 301, 307 (1958) (citing William Pitt, Earl of Chatham, Address to the House of Commons in England (1763))).

19. 552 N.W.2d 218 (Minn. 1996).

20. Id. at 219 .

21. Id.

22. Id

23. Id.

24. Id. at 221 .

25. Id. at 221-22.

26. See Terry v. Ohio, 392 U.S. 1 (1968) (holding that when a police officer reasonably believes a suspect might be engaged in criminal activity and reasonably believes that suspect might be armed, the officer is entitled to conduct a limited search of the suspect's outer clothing for weapons). 
situation by invading Andrea Wynne's privacy. ${ }^{27}$

Justice Tomljanovich acknowledged the realities of the duties of police officers, but again rested her analysis upon the respective roles of the executive and judicial branches.

We understand that in the excitement, and oftentimes the danger of a drug search, the officers do not have time to reflect on the parameters of Terry. We, however, do have that luxury. We have a duty to the citizens and to law enforcement officers to analyze the law carefully and set out clearly the limits of a search. In our experience law enforcement officers are not anxious to exceed the law, and for that reason we need to carefully define the limits of a search warrant. ${ }^{28}$

In State v. Carter, ${ }^{29}$ Justice Tomljanovich's majority opinion held that the right to privacy in the home encompassed persons visiting for commercial (albeit illegal) purposes. ${ }^{30}$ In Carter, the defendant was bagging cocaine in another person's apartment. ${ }^{31}$ A police officer, acting on a tip, observed this activity after he "left the sidewalk, walked across the grass, climbed over the bushes, placed his face within 12 to 18 inches of the window and peered through a small gap between the blinds . . .."32 Justice Tomljanovich's opinion held that the police officer had violated the defendant's Fourth Amendment rights. ${ }^{33}$

Although Justice Tomljanovich's opinion relied on the defendant's reasonable expectation of privacy, it also considered the case's ramifications on the privacy rights of home owners. "Although society does not recognize as valuable the task of bagging cocaine, we conclude that society does recognize as valuable the right of property owners or leaseholders to invite persons into the privacy of their homes to conduct a common task, be it legal or illegal activity." 34 She pointed out that "conduct that would constitute an illegal search does not become something less merely because the police had reasonable suspicion and embarked on a search of limited intrusiveness. As such, we once again reject

\footnotetext{
27. Wynne, 552 N.W.2d at 222.

28. Id.

29. 569 N.W.2d 169 (Minn. 1997), rev'd, 525 U.S. 83 (1998).

30. Id. at 176 .

31. Id. at 171 .

32. Id. at 178 .

33. Id. at 171 .

34. Id. at 176 .
} 
the notion that a little bit of information justifies a little bit of a search." ${ }^{35}$ The United States Supreme Court reversed this decision, holding that Carter, only there for a short period for business purposes, did not have a legitimate expectation of privacy. ${ }^{36}$

State v. Dickerson ${ }^{37}$ also implicated both privacy and Fourth Amendment rights. Justice Tomljanovich's majority opinion again refused to expand an exception to the warrant requirement. Under the Terry doctrine,

police may stop and frisk a person when (1) they have a reasonable, articulable suspicion that a suspect might be engaged in criminal activity and (2) the officer reasonably believes the suspect might be armed and dangerous. If both of those factors are present, police may "conduct a carefully limited search of the outer clothing of such person[] in an attempt to discover weapons which might be used to assault him.",

Justice Tomljanovich's opinion refused to extend this "plain view" exception to the "plain feel" of an object that could not conceivably be a weapon, in this case, a marble-sized lump of crack cocaine.

Because we do not believe the senses of sight and touch are equivalent, we decline to extend the plain view doctrine to the sense of touch. We reach this conclusion for two primary reasons. First, the sense of touch is inherently less immediate and less reliable than the sense of sight ... . But even more important, the sense of touch is far more intrusive into the personal privacy that is at the core of the fourth amendment . . . O Observing something that is held out to plain view is not a search at all. Physically touching a person cannot be considered anything but a search.

As in many of her opinions, Justice Tomljanovich's opinion in Dickerson demonstrated her use of common sense. In Dickerson, she rejected the police officer's testimony that he immediately identified a lump of crack cocaine by touch.

The officer's "immediate" perception is especially remarkable because this lump weighed 0.2 grams and was no bigger than a marble. We are led to surmise that the

35. Id. at 178-79.

36. Minnesota v. Carter, 525 U.S. 83, 91 (1998).

37. 481 N.W.2d 840 (Minn. 1992), aff'd, 508 U.S. 366 (1993).

38. Id. at 843 (quoting Terry v. Ohio, 392 U.S. 1, 30 (1968)).

39. Dickerson, 481 N.W.2d at 845 (citations omitted). 
officer's sense of touch must compare with that of the fabled princess who couldn't sleep when a pea was hidden beneath her pile of mattresses. But a close examination of the record reveals that like the precocious princess, the officer's "immediate" discovery in this case is fiction, not fact. ${ }^{40}$

The United States Supreme Court disagreed with the reasoning in Justice Tomljanovich's opinion, holding that "police officers may seize nonthreatening contraband detected during a protective patdown search of the sort permitted by Terry." ${ }^{41}$ It affirmed the judgment, however, because the officer's search of Dickerson had gone beyond what Terry allowed. ${ }^{42}$

In re Welfare of R.A.V., ${ }^{43}$ the well-known cross-burning case, required Justice Tomljanovich to balance two interests in which she firmly believed-constitutional protection of the right of free expression and jurisprudential principles constraining the court from running roughshod over the acts of the legislature. In R.A.V., a Saint Paul ordinance provided that

$[\mathrm{w}]$ hoever places on public or private property a symbol, object, appellation, characterization or graffiti, including but not limited to, a burning cross or Nazi swastika, which one knows or has reasonable grounds to know arouses anger, alarm, or resentment in others on the basis of race, color, creed, religion, or gender commits disorderly conduct and shall be guilty of a misdemeanor. ${ }^{44}$

Justice Tomljanovich's opinion observed that "[a]lthough the . . ordinance should have been more carefully drafted," ${ }^{45}$ the court was able to uphold it by following long-standing constitutional

40. Id. at 844 .

41. Minnesota v. Dickerson, 508 U.S. 366, 373 (1993).

42. Id. at 379 . "If a police officer lawfully pats down a suspect's outer clothing and feels an object whose contour or mass makes its identity immediately apparent, there has been no invasion of the suspect's privacy beyond that already authorized by the officer's search for weapons . . .." Id. at 375. Here, however, the officer was able to identify the contraband only after "squeezing, sliding and otherwise manipulating the contents of the defendant's pocket." Id. at 378 (citation omitted). Honoring function over form, Justice Tomljanovich categorizes Dickerson with the opinions reversed by the United States Supreme Court. E-mail from Justice Esther Tomljanovich to Ann Iijima, Professor of Law, William Mitchell College of Law (Nov. 21, 2003, 12:44 CST) (on file with author).

43. 464 N.W.2d 507 (Minn. 1991), rev'd sub nom R.A.V. v. City of St. Paul, 505 U.S. 377 (1992).

44. Id. at 508 .

45. Id. at 511 . 
principles. $^{46}$ "When possible ... this court narrowly construes a law subject to facial overbreadth attack so as to limit its scope to conduct that falls outside first amendment protection while clearly prohibiting its application to constitutionally protected expression." ${ }^{47}$ Accordingly, the court upheld the ordinance after narrowing its scope to apply only to "fighting words," that is, expression that is "directed to inciting or producing imminent lawless action and is likely to incite or produce such action." 48

In reversing this decision, the United States Supreme Court had to devise a new general principle. For the half-century leading up to R.A.V., the Court consistently held that fighting words did not constitute protected speech. ${ }^{49}$ In R.A.V., however, the Court modified this principle and held that a narrowly-tailored, but content-based restriction on fighting words would violate the First Amendment. ${ }^{50}$

Once again, in State v. Holmes, ${ }^{51}$ Justice Tomljanovich's opinion refused to expand the exceptions to the warrant requirement-in that case, the exception for inventory searches. A University of Minnesota parking monitor discovered that an illegally parked vehicle had five unpaid parking tickets. ${ }^{52}$ She ordered the vehicle to be towed. ${ }^{53}$ When Holmes returned to his car, the parking monitor felt intimidated and called the University police department for assistance, despite the fact that Holmes had been respectful and cooperative. ${ }^{54}$ The officer asked Holmes for identification and patted him down, finding a weapon's magazine clip. ${ }^{55}$ Although the parking monitor had already looked into the vehicle to inventory any items, the officer searched the vehicle again, finding an empty gun case on the floor and a handgun in

46. Id. at 509 .

47. Id.

48. Id. at 510 (quoting Brandenburg v. Ohio, 395 U.S. 444, 447 (1969)).

49. See, e.g., Chaplinsky v. New Hampshire, 315 U.S. 568 (1942).

50. R.A.V. v. City of St. Paul, 505 U.S. 377, 377 (1992). This was not the only case in which the United States Supreme Court contrived a new legal principle in response to Justice Tomljanovich's opinions. See Minnesota v. Dickerson, 508 U.S. 366 (1993) (affirming Dickerson but adopting "plain feel" exception to warrant requirement). See supra notes $41-42$ and accompanying text.

51. 569 N.W.2d 181 (Minn. 1997).

52. Id. at 182 .

53. Id.

54. Id. at 183 .

55. Id. 
the glove compartment. ${ }^{56}$ Holmes apparently admitted that the handgun was his and that he did not have a permit to carry it. ${ }^{57} \mathrm{He}$ was charged with unlawful possession of a pistol. ${ }^{58}$

In her majority opinion, Justice Tomljanovich, writing for a unanimous court, held that the trial court had not erred in suppressing the pistol and the defendant's statements, articulating the criteria for a valid inventory search. ${ }^{59}$ She confirmed that the police may make a warrantless search of an impounded vehicle in order to inventory the items. ${ }^{60}$ She stated, however, that there are limits to this exception. ${ }^{61}$ The court will find such a search to constitute "a reasonable inventory search only if police followed standard procedures in conducting the search, and only if police conducted the search, at least in part, for the purpose of obtaining an inventory." ${ }^{62}$ She noted that "searches conducted 'in bad faith or for the sole purpose of investigation,' are not otherwise valid as inventory searches." ${ }^{33}$ She acknowledged that making that determination might be difficult, but "suggested that faith is 'bad' and investigative purpose 'sole' only when an inventory search that otherwise would not have occurred is brought about." ${ }^{64}$ Because the search had been for the purpose of finding the pistol, it was not a valid inventory search and did not fall within that exception to the warrant requirement. ${ }^{65}$

Although often protective of the constitutional rights of criminal defendants, Justice Tomljanovich's positions were based firmly on the Constitution, rather than on any particular prodefendant sympathies. Her opinions permitted police officers to perform their jobs effectively while they protected the procedural and substantive rights of the accused. In a number of cases, her opinions upheld the state's actions against even arguably sympathetic defendants.

For example, in State v. Pike, ${ }^{66}$ Justice Tomljanovich's opinion

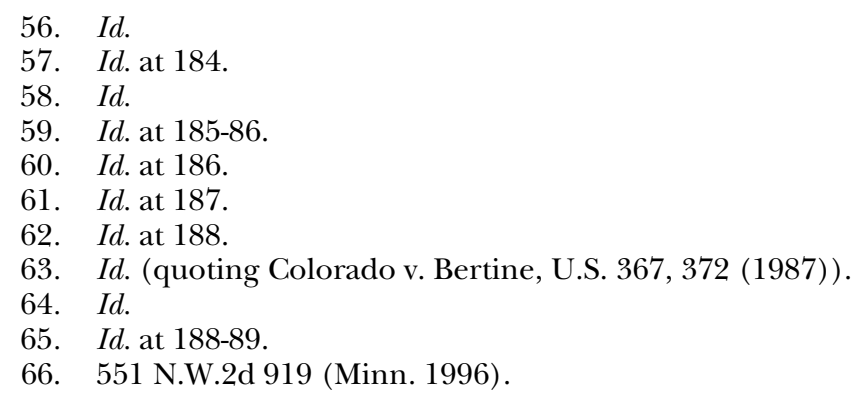


held that the State had "clearly and unequivocally" proven that the trial court erred in dismissing gross misdemeanor charges against a defendant. $^{67}$ The police officer claimed to have stopped Pike's vehicle because it was driving slowly, its owner's license had been suspended, and the driver matched the owner's description. ${ }^{68}$ The district court, not believing that the officer based his stop on the vehicle's speed or that the officer had been able to see the driver, dismissed the case, finding that the stop had been "the product of mere whim, caprice or idle curiosity." ${ }^{, 69}$ Justice Tomljanovich's opinion stated that, although warrantless searches are generally per se unreasonable, a "limited investigative stop is lawful if the state can show the officer to have had a "particularized and objective basis for suspecting the particular person stopped of criminal activity." ${ }^{70}$ It observed that, even if two of the officer's three rationales for stopping the defendant were disregarded, the remaining rationale provided sufficient justification:

We hold that it is not unconstitutional for an officer to make a brief, investigatory, Terry-type stop of a vehicle if the officer knows that the owner of the vehicle has a revoked license so long as the officer remains unaware of any facts which would render unreasonable an assumption that the owner is driving the vehicle. ${ }^{71}$

As was her preference, Justice Tomljanovich's opinion set out a clear rule for police officers and reviewing courts.

Justice Tomljanovich believed in the ability of a properly functioning legal system to produce justice. Accordingly, her decisions often focused on maintaining the proper balance between the branches of government and on ensuring the proper role of judges and attorneys.

In State v. Krotzer, ${ }^{72}$ Krotzer, a nineteen-year-old man, had consensual sexual intercourse with his fourteen-year-old girlfriend. $^{73}$ After failing to reach a plea agreement with the prosecutor, Krotzer pleaded guilty to statutory rape. ${ }^{74}$ The district court did not accept the plea agreement and, instead, granted

67. Id. at $921-22$.

68. Id. at 921 .

69. Id.

70. Id. (quoting United States v. Cortez, 449 U.S. 411, 417-18 (1981)).

71. Id. at 922 .

72. 548 N.W.2d 252 (Minn. 1996).

73. Id. at 253 .

74. Id. 
Krotzer's request to stay adjudication of the charge. ${ }^{75}$ It placed Krotzer on probation and ordered him to serve sixty days in jail and to pay fines, fees, and surcharges. ${ }^{76}$ The district court apparently overrode the prosecutor's decision to try Krotzer for a felony because of extenuating circumstances: Krotzer and his girlfriend were no longer engaging in sexual relations, the girl and her mother did not want to have Krotzer prosecuted, and Krotzer would have had to register as a sex offender, despite the lack of a history of aggressiveness. ${ }^{77}$

Justice Tomljanovich's dissent emphasized the separation of powers issue. "Our system of government works because each of the three branches respects the authority of the other-even when we think we could do their job better than they do. The majority has permitted the courts to encroach into an area reserved to the executive branch by the Constitution." ${ }^{, 7}$ Justice Tomljanovich disagreed with the lenient treatment of the defendant and would have relied on the statute's purpose of protecting minors and on the lack of statutory authority for the district court's action. ${ }^{79}$ Her opinion emphasized her respect for legislative policy-making powers and her disapproval of court overreaching. In her typically straight-forward style, she stated, "I am at a loss to understand how the court can put a person on probation and order jail time when the court has not accepted a guilty plea and adjudged the person guilty." 80

\section{Id.}

76. Id.

77. Id. Justice Tomljanovich apparently did not find the defendant particularly sympathetic, stating that

[t] he majority notes that the victim's mother felt the court should 'let it end' without prosecution. It is incredible that the victim's mother has given 'her blessing' to the relationship to preserve her good relationship with her daughter. This law is designed to protect the minor victim from her own immature judgment and that of her mother if necessary.

Id. at 260.

78. Id.

79. Id.; see also Mark H. Zitzewitz, Comment, State v. Krotzer: Inherent Judicial Authority-Going Where No Court Has Gone Before, 81 MinN. L. REv. 1049 (1997) (examining the holding of Krotzer and arguing that the Minnesota Court of Appeals and the Minnesota Supreme Court erred in finding that inherent judicial powers include the ability to stay adjudication of criminal prosecutions).

80. Krotzer, 548 N.W.2d at 260 (Tomljanovich, J., dissenting). 


\section{Civil CASES}

Justice Tomljanovich's reverence for the home was apparent in her civil opinions, as well as in her criminal opinions. In Wegner $v$. Milwaukee Mutual Insurance Co., ${ }^{81}$ a police SWAT team used tear gas and flash-bang grenades to apprehend an armed suspect, causing over $\$ 70,000$ in damages to Wegner's home. ${ }^{82}$ Justice Tomljanovich, writing for a unanimous court, held "that where an innocent third party's property is damaged by the police in the course of apprehending a suspect, that property is damaged within the meaning of the constitution," ${ }^{83}$ and the municipality must "compensate the innocent party for the resulting damages." Wegner, the court was presented with a number of complex constitutional issues, including eminent domain, takings, and the doctrine of public necessity. These analyses required the court to weigh the responsibility of the police to protect the general public against the harm to innocent parties. Justice Tomljanovich concluded:

The policy considerations in this case center around the basic notions of fairness and justice. At its most basic level, the issue is whether it is fair to allocate the entire risk of loss to an innocent homeowner for the good of the public. We do not believe the imposition of such a burden on the innocent citizens of this state would square with the underlying principles of our system of justice.

Justice Tomljanovich, however, made it clear "that the individual police officers, who were acting in the public interest, cannot be held personally liable. Instead, the citizens of the City should all bear the cost of the benefit conferred."

81. 479 N.W.2d 38 (Minn. 1991).

82. Id. at 39 .

83. Id. at $41-42$.

84. Id. at 42 .

85. Id.

86. Id. Justice Tomljanovich's respect for law enforcement personnel was apparent in a number of other cases. For example, in McDonnell v. Commissioner of Public Safety, the court considered a Minnesota statute allowing police to require drivers to submit to alcohol tests. 473 N.W.2d 848 (1991). This statute allowed the suspect to consult with an attorney, but not until after submitting to testing. $I d$. at $850 \mathrm{n} .1$. Justice Tomljanovich's opinion conceded that there is no right to counsel under the Sixth Amendment of the United States Constitution until after formal charges have been made. Id. at 853. It pointed out, however, that the Minnesota Constitution provided a right to counsel at the time an individual is asked to take a blood alcohol test. Id. The court had just adopted that 
In Miller v. Colortyme, Inc., ${ }^{87}$ Justice Tomljanovich, writing for a unanimous court, determined that the anti-usury provisions of the Consumer Credit Sales Act applied to rent-to-own transactions. ${ }^{88}$ Her opinion observed that "[t] he purpose of the usury law is to protect consumers by limiting the amount of interest which can be charged on a credit sale or loan. ${ }^{, 99}$

The legislature's decision to treat rent-to-own transactions as credit sales recognizes that although these transactions purport to be short-term leases, they operate in substance much like ordinary installment sales. Consumers who purchase goods through rent-to-own agreements may not incur debt, but they still implicitly pay interest in return for the ability to pay for goods over time. Moreover, rentto-own customers may not have an absolute obligation to repay a principal amount, but their situation is analogous to that of ordinary buyers on credit in that they must either forfeit possession of a good or continue paying for it. $^{90}$

Justice Tomljanovich noted that, under a number of the transactions in question, the customers would have paid about twice the stated cash prices by the time they actually owned the purchased goods. ${ }^{91}$

Justice Tomljanovich's concurring opinion in Bilal v. Northwest

interpretation of the state constitution that same day in another case. Id. Justice Tomljanovich mitigated the impact that this new rule would have on law enforcement personnel:

Generally, decisions of this court overruling past decisions are given retroactive effect. However, given the reasonable reliance of law enforcement officials on prior decisions of this court . . . and given the enormous burden on the administration of justice that would result from giving Friedman completely retroactive effect, we limit the application of Friedman to the three appeals now before this court, to any case in which the Implied Consent Advisory has been challenged as a violation of the right to counsel guaranteed by the Minnesota Constitution now pending ... and to any case arising after the date of Friedman's release.

$I d$. (citation omitted). Her opinion also held that the Constitution does not allow the police to threaten drivers refusing to submit to testing with potential criminal penalties that could not be imposed on them, but it did allow use of a driver's refusal to submit to testing as evidence that the driver was intoxicated. Id. at 855 .

87. 518 N.W.2d 544 (Minn. 1994).

88. Id. at 546 .

89. Id. at 549 .

90. Id.

91. Id. at 546 . 
Airlines, Inc. ${ }^{92}$ evidences both her fondness for common sense and her understanding of the important yet limited role of the judiciary. In that case, the spouse of an airline employee, traveling as a non-revenue passenger, was wearing sandals without stockings in violation of the airline's dress code. ${ }^{93}$ An airline employee, not knowing that the passenger was Muslim, told her that she should dress as if she were "going to church." ${ }^{44}$ Justice Anderson, writing for a unanimous court, held that the airline employee had not intentionally engaged in religious discrimination, observing that the employee had not even known that the passenger was Muslim. ${ }^{95}$ Justice Tomljanovich concurred specially:

I concur with the result reached by the majority, but write to express my concern that this matter ever reached the courts. It is important to be sensitive to racial, religious and gender differences and to avoid discrimination. However, this lawsuit defies common sense.

The majority pointed out that the word "church" does not possess the inherent derogatory qualities of an epithet. I agree. I believe that a chance remark such as the one in this case that was not motivated by any discriminatory intent should not be actionable just because it includes the word "church."

We must eliminate the use of language that diminishes another person's humanity, but this surely was not such language. How much better it would have been when Ms. Bilal was offended by Ms. Patrick's reference to church if she had sat down with Ms. Patrick and her supervisors and explained her feelings. An apology and a better understanding of the situation would, no doubt, have resulted. The courts simply cannot be the arbitrator of all hurt feelings.

It is important that we communicate our feelings to one another, but if we must live in fear that a lawsuit will result each time we make a comment or use a word that someone, somewhere, sometime might find offensive, all human exchange of words and ideas will cease, and our

92. 537 N.W.2d 614 (Minn. 1995).

93. Id. at 616 .

94. Id.

95. Id. at 619 . 
world will be a worse place in which to live. ${ }^{96}$

Dziubak v. Mott ${ }^{97}$ also focused on the role of the judicial system, requiring the court to balance the interests of criminal defendants and the needs of the criminal justice system. Justice Tomljanovich's majority opinion granted immunity to the public defenders in Dziubak's suit against his state public defenders for malpractice. $^{98}$ Although, like the dissenters, Justice Tomljanovich was concerned about denying a remedy to indigent defendants, she took a longer view, focusing on the practical effects of extending or withholding immunity from public defenders. ${ }^{99}$ She distinguished the relative positions of criminal defense lawyers in the public and private sectors, observing that public defenders are required to represent the clients assigned to them, regardless of the size and difficulty of their caseloads. ${ }^{100}$ She also recognized the lack of resources available to the office of the public defender. ${ }^{101}$ "It would be an unfair burden to subject the public defender to possible malpractice for acts or omissions due to impossible caseloads and an under-funded office: something completely out of the defender's control." ${ }^{\text {102 }}$

Since justice demands that a defense be provided to criminal defendants who are not able to afford privately retained counsel, it is essential that a sufficient number of qualified attorneys be willing and able to provide this defense. Immunity will aid in the continued recruitment of attorneys to perform this service in our criminal justice system; such service is eagerly sought by most attorneys. The accused defendant is not the sole beneficiary. Society as a whole depends upon the role of defense counsel to secure an ordered system of liberty and justice, as ordained by our Constitution.

The extension of immunity to public defenders will ensure that the resources available to the public defender will be used for the defense of the accused, rather than diminished through the defense of public defenders against civil suits for malpractice. Immunity will conserve

96. Id. at 620 (Tomljanovich, J., concurring).

97. 503 N.W.2d 771 (Minn. 1993).

98. Id. at 773 .

99. Id. at 776 .

100. Id. at 775 .

101. Id. at 776 .

102. Id. 
these resources to provide an effective defense to the greatest number of indigent defendants. ${ }^{103}$

Nicollet Restoration, Inc. $v$. Turnham ${ }^{104}$ required the court to consider the division of powers among the branches of government. In that case, Justice Tomljanovich, writing for a unanimous court, held that a corporation appearing in district court had to be represented by a licensed attorney, even when the matter arose in conciliation court. ${ }^{105}$ She reasoned that, despite the fact that a Minnesota statute could be read to give corporations the power to appear in court through non-attorney officers, such a reading would violate the state constitution. ${ }^{106}$

Since corporations are distinct legal entities, any individual attempting to appear on behalf of the corporation would, in effect, be practicing law. Based on the legislature's power to enact criminal statutes, it is clear that the legislature has the authority to determine who may or may not be prosecuted for the unauthorized practice of law. This, however, does not mean that the legislature may decide who may properly practice law before the courts of this state. Under Article 3, Section 1 of the Minnesota Constitution, this power is vested solely in the judiciary. ${ }^{107}$

She discussed the policies underlying the attorney requirement, pointing out that a "non-attorney agent of a corporation is not subject to the ethical standards of the bar and is not subject to court supervision or discipline. The agent knows but one master, the corporation, and owes no duty to the courts."108 Moreover, she observed that, "[i]f district courts are to handle their increasingly crowded and complex dockets efficiently and justly, it is important that clients' causes be presented by persons trained

\footnotetext{
103. Id. at $777-78$.

104. 486 N.W.2d 753 (Minn. 1992).

105. Id. at 753 .

106. Id. at 755 .

107. Id. (citing Minneapolis Star \& Tribune Co. v. Hous. \& Redev. Auth., 310 Minn. 313, 318, 251 N.W.2d 620, 623 (1976)). Article III, section 1 of the Minnesota Constitution provides: "The powers of government shall be divided into three distinct departments: legislative, executive and judicial. No person or persons belonging to or constituting one of these departments shall exercise any of the powers properly belonging to either of the others except in the instances expressly provided in this constitution.” Id. (citing MinN. CONST. art. III, § 1).

108. Id. at 754 .
} 
and licensed to do so."109

\section{COnClusion}

Some jurists believe that one should first determine what justice requires and then use the law to achieve that result. In contrast, because Justice Tomljanovich typically follows the law rather than her own predilections, her decisions cannot consistently be labeled either "liberal" or "conservative." Unable to predict which side of a controversy Justice Tomljanovich will take-state or criminal defendant, plaintiff or defendant-some might criticize her jurisprudence as "inconsistent." At a deeper level of analysis, however, Justice Tomljanovich's opinions are consistent. They reflect an abiding belief in the power of the law to achieve justice - a belief that, by following the dictates of the law, justice generally will result. They demonstrate a belief in the structural provisions of the United States and Minnesota Constitutions. They show a respect for the separation of powers between the federal and state governments and for the division of powers among the governmental branches. They also evidence her belief in both the desire and ability of people at the heart of the government bodies to perform their roles with competence and integrity.

Justice Tomljanovich's judicial philosophy was consistent with her approach to her work-it was not about her, her ego, or her view of the law. She said that she found the greatest satisfaction not from the ego satisfaction, nor from deciding big cases, but from the opportunity to make a difference in someone's life, to have a positive influence at a critical juncture in that person's life. "The job is incredibly important, but you're not. It's real important that

109. Id. at 755 .

110. Her official actions, as well as her opinions, demonstrated a lack of partisanship. She was appointed to the Minnesota Supreme Court in 1990 by Governor Rudy Perpich. AnNa Cherry et AL., 100 Who Made a Difference 16 (2001). Although she was appointed by Governor Perpich, a Democrat, the timing of her resignation permitted Governor Arnie Carlson, a Republican, to fill the vacancy. Robert Whereatt, Tomljanovich to Retire From High Court; She Helped Lead Way For Women on Bench, STAR TriB., May 1, 1998, at 1B. Although her April, 1998 resignation did not become effective until August, 1998, it allowed Governor Carlson to name her successor before filings for the office opened in July of 1998. Id. This action kept the judicial post out of the election process, and her successor did not have to run for re-election until 2000. Id. 
you have people who know that."

111. Christine Krueger, Three Paths to Leadership: A Study of Women on the Minnesota Supreme Court 18 (1994) (statement of Justice Tomljanovich). 